\title{
Kepribadian dan Agresivitas dalam Berbagai Budaya
}

\author{
Nur Afiah \\ Program Studi Magister Psikologi \\ Fakultas Psikologi Universitas Gadjah Mada
}

\section{Pengantar}

Agresif dan perilaku kekerasan bukanlah merupakan fenomena yang baru. Agresif dan perilaku kekerasan telah terjadi sejak 25.000 tahun yang lalu antara masyarakat Yunani, Mesir, dan Romawi. Peristiwa, seperti Holocaust, penembakan sekolah Columbine, di Colorado, atau serangan teroris di World Trade Centre pada 11 September 2001 yang membuat masyarakat bertanya-tanya dibalik terjadinya perilaku kekerasan tersebut. Prevalensi perilaku agresif dan kekerasan saat ini sudah cukup banyak dijadikan sebagai pemicu timbulnya masalah sosial yang layak menjadi perhatian di seluruh dunia.

Tingkat angka kematian biasanya dianggap sebagai ukuran terjadinya tindak kekerasan. Berdasarkan sejarah, tingkat kekerasan antar pribadi dalam lingkungan masyarakat disebabkan karena adanya faktor demografi dan faktor lainnya. Misalnya saja, di Amerika Serikat, tingkat pembunuhan berada pada level yang tinggi (Surgeon General, 2001), 6,5 kasus pembunuhan per 100.000 orang merupakan masalah sosial yang serius. Agresif pada manusia biasanya didefinisikan sebagai perilaku yang mengarahkan individu dengan tujuan untuk menyebabkan kerusakan atau kerugian terhadap orang lain maupun lingkungan. Geen

\footnotetext{
${ }^{1}$ Korespondensi mengenai isi artikel ini dapat melalui: nurafiahspsi@yahoo.co.id
}

(2001) menjelaskan bahwa kekerasan merupakan agresi fisik yang secara berkelanjutan dapat menduduki tingkat yang paling tinggi, seperti timbulnya penyerangan yang sangat ekstrim hingga menyebabkan kematian. Tulisan ini memaparkan perilaku agresif pada budaya siri' na pesse pada masyarakat BugisMakassar dan budaya carok dan celurit pada masyarakat Madura.

Budaya Siri' na pesse pada masyarakat BugisMakassar

Kata siri' na pesse' merupakan dua kata yang berlawanan tetapi pada dasarnya saling melengkapi yang oposisinya diperlihatkan dalam aplikasi kehidupan sehari-hari. Kekuatan siri' na pesse' menjadi baku dalam kebudayaan BugisMakassar secara faktual (imbasadi.com). Semua peristiwa, seperti konflik, perang, kedamaian, dan cinta merupakan kekuatan yang tidak tampak dan tidak semuanya bisa dibahasakan pada kehidupan masyarakat Bugis-Makassar. Siri' dipandang sebagai rasa malu dan harga diri. Pandangan tersebut menyebabkan masyarakat Bugis-Makassar tumbuh menjadi sangat individual. Pandangan pesse merupakan hal yang berkaitan dengan kecerdasan emosi untuk turut merasakan kepedihan atau kesusahan individu dalam kelompok. Hal tersebut dapat dilihat ketika keluarga ataupun kelompoknya sedang dalam kondisi sulit, menderita, ataupun mengalami penganiayaan oleh pihak luar, maka 
pandangan pesse yang berbicara yang merupakan bentuk rasa cinta, sedih, perih, kesetiakawanan terhadap keluarga ataupun kelompok. Nyawapun akan menjadi taruhannya demi membela keluarga. Salah satu kalimat yang dikutip, yaitu "nakko teani temmakku, siri' na naranreng, nyawae mani tu assukerenna, artinya bahwa jika memang sudah tidak ada jalan lain, siri' harus ditegakkan maka nyawalah taruhannya.

Penjelasan di atas merupakan dua hal yang berlawanan, namun saling mendukung yang dimiliki dan merupakan kekuatan masyarakat Bugis-Makassar. Siri' na pesse dapat diwujudkan dengan memanfaatkan aturan main yang membuka peluang timbulnya persaingan ketat tanpa harus menimbulkan perilaku anarkis yang dapat membahayakan kehidupan masyarakat luas. Masyarakat BugisMakassar menjunjung tinggi solidaritas, sehingga keadilan bukanlah merupakan masalah etika, akan tetapi lebih mengarah pada fair play. Perilaku kekerasan ditempuh demi menegakkan siri'. Hal tersebut dilakukan apabila memang sudah tidak ada lagi jalan lain demi mencapai kebaikan dan kedamaian. Sekali masyarakat Bugis-Makassar maju untuk menempuh kesulitan yang bertujuan untuk membela kebenaran, maka haram hukumnya untuk mundur. Terdapat beberapa falsafah hidup masyarakat Bugis-Makassar sebagaimana yang telah dijelaskan dalam buku Lontara. Pertama, jangan permalukan dia, sebab masyarakat Bugis-Makassar memilih untuk mati dari pada dipermalukan. Kedua, jangan kecewakan dia, sebab apabila dikecewakan, maka masyarakat Bugis-Makassar akan meninggalkan Anda. Dari sikap mental tersebut kemudian menjadi salah satu akar superioritas kolektif yang memiliki potensi terjadinya kekerasan ketika terjadi suatu hal yang mengancam harga diri dan kepercayaan masyarakat Bugis-Makassar. Sikap mental tersebut kemudian telah menjadi watak dalam alam bawah sadar pada setiap masyarakat Bugis-Makassar.

Beberapa budayawan memandang bahwa konsep siri' na pesse merupakan unsur penting dalam membentuk mental masyarakat Bugis-Makassar. Konsep tersebut kemudian dianggap sebagai hal yang berperan dalam beberapa perilaku masyarakat setempat, termasuk perilaku kekerasan. Berbicara tentang perilaku kekerasan dan konflik, Makassar selalu menjadi daerah yang banyak menarik perhatian bagi sebagian masyarakat Indonesia. Beberapa tindakan kekerasan banyak terjadi di kalangan mahasiswa, antar kelompok, bahkan sampai geng motor, dimana perilaku tersebut sangat meresahkan warga setempat.

Carok dan Celurit pada masyarakat adat Madura

Budaya carok dan celurit pada masyarakat Madura, dapat dijelaskan bahwa pada awalnya penggunaan celurit bertujuan untuk melawan penjajah Belanda. Akan tetapi pada zaman Cakraningrat, budaya yang terjadi adalah pembunuhan yang menggunakan pedang dan keris saja. Kemunculan budaya celurit, selain karena untuk melawan penjajah, juga berawal dari adanya kebiasaan mandor yang setiap harinya membawa celurit ketika mengawasi para pekerja yang berada di kebun. Celurit tersebut memiliki simbol sebagai bentuk perlawanan rakyat jelata. Lebih lanjut, pemaparan terkait carok merupakan istilah yang berhubungan dengan perkelahian yang melibatkan dua atau lebih keluarga besar, antar kelompok, dan antar wilayah. Pemicu perkelahian atau carok berawal dari adanya sengketa wilayah, kedudukan, kekuasaan, perselingkuhan, 
dan tak jarang merupakan dendam turuntemurun.

Pada budaya masyarakat Madura, carok merupakan simbol dalam pembelaan harga diri atau kehormatan terkait masalah kedudukan, kekuasaan, harta, dan istri. Budaya carok telah menjadi ikon masyarakat Madura sejak dahulu kala. Perkelahian yang terjadi pada masyarakat Madura tidak lepas dengan celurit yang juga merupakan simbol senjata masyarakat tersebut. Celurit tersebut juga sering digunakan tindak demonstrasi dan kerusuhan.

Berdasarkan dua pemarapan di atas terkait budaya dan perilaku agresif, kedua wilayah tersebut memiliki kesamaan budaya, yaitu sama-sama berjiwa kesatria demi mempertahankan harga diri atau kehormatan. Kekerasan yang terjadi tidak jarang akan berujung pada kematian. Watak yang keras pada dua masyarakat di atas telah terbentuk karena budaya yang sudah ada sejak dulu dan telah mendarah daging dalam alam bawah sadar pada kedua masyarakat tersebut.

Gerakan dari pandangan teoritis yang mengintegrasikan efek dari faktor biologis dan faktor lingkungan sosial, dideskripsikan bahwa terbentuknya perilaku agresi karena adanya kecenderungan biologis individu yang menampakkan dirinya melalui interaksi dengan konteks sosial dimana individu tersebut hidup dan berkembang (Raine, dkk., 1997). Efek dari proses biologis yang meliputi proses kognitif sosial tentunya memberikan pengaruh pada struktur pengetahuan, seperti keyakinan, skema, dan sikap. Beberapa penelitian juga menyebutkan bahwa terdapat beberapa hal terkait dengan perilaku agresif, diantaranya adanya normanorma budaya yang berbeda tentang kekerasan (Nisbett \& Cohen, 1996). Selain itu, adanya kesiapan pribadi yang terda- pat dalam konteks sosial kognitif yang dipandang sebagai kumpulan struktur kognitif dan kecenderungan emosional yang memengaruhi perilaku dalam interaksi dengan masyarakat.

Perilaku kekerasan yang terjadi seperti yang telah dipaparkan menunjukkan adanya ketidakmampuan dalam mengelola emosi. Schultz, Izard, dan Bear (2004) menjelaskan bahwa atribut emosi memiliki hubungan dengan perilaku agresif. Penjelasan proses emosi dan agresif dapat dilihat dari beberapa penelitian terbaru yang menjelaskan bahwa setiap anak memiliki tingkat agresivitas yang berbeda. Hal tersebut disebabkan karena adanya perbedaan informasi dalam memeroses emosi. Perilaku agresif yang terjadi pada anak-anak biasanya disebabkan karena kurangnya rasa empati. Anak-anak terkadang meniru perilaku marah berdasarkan dengan sesuatu yang dilihatnya. Perilaku tersebut terjadi diawal bulan kelahiran anak dan kemudian bertahan sampai umur empat atau lima tahun. Berdasarkan perspektif perkembangan, perilaku agresif pada masa anak-anak secara signifikan disebabkan karena kualitas hubungan interpersonal yang rendah. Penelitian yang dilakukan oleh Chen, dkk. (2010) pada anak-anak di China yang berumur delapan tahun yang bertujuan untuk melihat kontribusi agresif terhadap perkembangan kompetensi dan pencapaian akademik. Secara empiris, perilaku agresif anak-anak di Cina berhubungan dengan lingkungan sosial, sekolah, dan masalah psikis. Penelitian yang dilakukan oleh Chen, Huang, Chang, dan Li (2010) menjelaskan bahwa sosial dan prestasi memiliki hubungan yang signifikan terhadap perilaku agresif. Hal tersebut tentunya akan berkembang pada tahap perkembangan selanjutnya. 
Berdasarkan pemaparan di atas, terbentuknya perilaku agresif tidak lepas dari adanya atribut emosi dan lingkungan sosial. Perilaku agresif secara konsisten muncul karena kurangnya kemampuan dalam menjalin hubungan secara interpersonal dan rendahnya kematangan emosi. Individu yang memiliki kematangan emosi yang tinggi akan mampu mengendalikan diri dari perilaku agresif (Guswani \& Kawuryan, 2011). Goleman (Desmita, 2006) menjelaskan bahwa emosi merupakan perasaan atau afeksi yang berasal dari komponen fisiologis kemudian membentuk perilaku. Perilaku tersebut akan menjadi dimensi psikologis yang bersifat menetap, menjadi kebiasaan, atau perangai pada setiap individu sehingga dapat digunakan untuk membedakan kepribadian antara individu satu dengan lainnya.

Mousazadeh dan Asgharzadeh (2012) mengemukakan bahwa kekerasan dan agresif merupakan isu global yang terjadi saat ini dan memiliki dampak yang dapat merusak fisik dan psikis. Sebagai akar dari permasalahan, berbagai kejahatan, seperti perang, penyimpangan sosial, dan kekerasan lainnya. Agresif dianggap sebagai perilaku yang dikombinasikan dengan kekerasan. Hal tersebut dijelaskan bahwa setiap perilaku yang merusak, berbahaya baik secara fisik maupun psikis yang ditujukan kepada orang lain. Perilaku agresif berhubungan dengan tiga faktor, yaitu biologi, sosial, dan psikologi. Secara teoritis, konsep dari agresif memiliki dua pendekatan, yaitu orientasi karena faktor bawaan dan orientasi karena faktor lingkungan. Pada pendekatan yang berorientasi pada faktor bawaan memandang bahwa perilaku agresif terjadi secara spontan dan tidak dapat dihindari. Freud, Lorenz, dan Wilson (Schultz, Izard, \& Bear, 2004) mengemukakan bahwa faktor biologis merupakan teori yang sangat penting dalam perilaku agresif. Sedangkan orientasi lingkungan memandang bahwa perilaku agresif terjadi karena adanya respons dari stimulus yang terjadi di lingkungan yang buruk, seperti frustrasi, peristiwa yang menyedihkan, berbahaya, serta ancaman yang juga berasal dari lingkungan.

\section{Budaya dan Kepribadian}

Perkembangan kepribadian merupakan hasil dari interaksi antara faktor bawaan dan lingkungan (Castillo, 1997). Lebih lanjut dijelaskan bahwa setiap individu belajar tentang bahasa, sistem kepercayaan, aturan-aturan dalam lingkungan sosial, dan perilaku yang sesuai dengan aturan atau norma yang terdapat dalam suatu wilayah. Salah satu konsep yang berhubungan dengan studi mental illness pada penelitian kepribadian secara antropologi adalah perbedaan antara struktur kepribadian sosiosentrisme dan egosentrisme. Dalam psikologi lintas budaya, perbedaan tersebut biasanya dihubungkan sebagai kolektivisme versus individualisme. Kepribadian sosiosentrisme merupakan sebuah struktur kepribadian dimana pusat identitas berada pada kelompok atau masyarakat. Individu yang berada pada kelompok tersebut terbentuk dari identitas primer yang berasal dari anggota kelompok dalam masyarakat yang pada akhirnya akan membentuk satu kesatuan. Struktur kepribadian egosentrisme merupakan identitas kepribadian yang berpusat pada diri individu sendiri. Individu memandang dirinya sendiri dengan beberapa pilihan, keinginan, dan kebenaran secara personal. Egosentrisme dan sosiosentrisme memegang peranan penting dalam perkembangan kepribadian dengan tujuan untuk mencapai kesejahteraan satu sama lain, baik secara kelompok maupun untuk kepentingan diri 
sendiri. Berikut ini dipaparkan struktur kepribadian ditinjau dari bentuk budaya pada beberapa negara di dunia (Castillo, 1997), antara lain:

\section{Budaya dan kepribadian di India}

India merupakan negara dengan masyarakat sosiosentrisme yang terbentuk dari identitas primer dalam keluarga dan kasta. Penjelasan tentang penindasan yang terjadi di India secara khusus dipaparkan dimana perempuan-perenpuan dan individu yang memiliki hukum dan kasta yang rendah akan mendapatkan penindasan dari kelompok yang lebih dominan atau memiliki kasta yang lebih tinggi. Dari religiusitasnya, masyarakat India mayoritas menganut kepercayaan Hindu. Kepercayaan Hindu dalam karma pada dasarnya menjadikan setiap individu fatalistic, penerimaan akan tempat tinggal dalam hidupnya tanpa adanya harapan untuk dapat mengembangkan kondisi ataupun keadaan yang diterima oleh individu tersebut. Bentuk penindasan yang terjadi di India merupakan bentuk domidasi kekerasan secara hirarki dalam lingkungan masyarakat sosiosentrisme yang secara luas membetuk sikap dalam masyarakat tersebut.

\section{Budaya dan kepribadian di Senoi Temiar}

Senoi Temiar merupakan masyarakat yang hidup di hutan hujan di Malaysia. Senoi Temiar memiliki egalitarian yang tinggi, sosisentrisme, dan premodern yang tinggi. Pada dasarnya masyarakat Senoi Temiar akan menjadi damai ketika sosiesentrisme dikombinasikan secara hirarki, tidak adanya eksploitasi dan kekerasan dalam masyarakat tersebut. Beberapa bentuk kekerasan fisik, seperti ekspresi marah dalam interaksi tatap muka tidak digunakan dalam masyarakat Senoi Temiar. Pada dasarnya ekspresi marah merupakan kekerasan fisik yang secara tidak langsung digunakan dalam "Harangue". Dalam sebuah Harangue, seseorang yang marah ketika menunggu sampai pertengahan malam dan kemudian menyampaikan pesan kepada seseorang yang berselisih. Hal tersebut selalu terjadi dalam ruang atau tempat yang terpisah, dan biasanya terjadi pada orang ketiga. Secara tidak langsung, peristiwa tersebut merupakan hal yang akan memengaruhi terbentuknya perilaku agresif dalam interaksi pada masyarakat Senoi Temiar.

\section{Budaya dan kepribadian di Swat Pukhtum}

Swat Pukhtum merupakan masyarakat yang hidup di pegunungan Pakistan bagian utara. Masyarakat tersebut sangat hirarkis, egosentrisme yang tinggi, dan premodern. Dominasi hirarki pada masyarakat tersebut berdasarkan pada jender dan kekayaan, serta pembentukan sebuah lingkungan sosial terhadap perilaku agresi dan kekerasan. Lingkungan sosial Pukhtun sangat keras dan kompetitif. Kombinasi tersebut merupakan sebuah kekuatan dan kehormatan. Dalam masyarakat Pukhtun, terdapat dua jenis yang menggambarkan kepribadian individu, yaitu kelemahan dan kekuatan. Kekuatan diperoleh dari kelemahan, dominasi masyarakat setempat, dan pencapaian kehormatan. Sedangkan kelemahan dapat dikontrol, dieksploitasi, dan didominasi dari kekuatan.

\section{Budaya dan kepribadian di Jepang}

Masyarakat Jepang dapat dideskripsikan sebagai hirarki moderasi, sosiosentrisme, dan modern. Jepang telah melakukan sebuah penindasan terhadap hirarki dominasi jender, moderate class, dan rasio dan etnik secara hirarki. Lingkungan sosial di Jepang dapat dikategorikan sebagai hirarki secara moderat dan modern yang 
menyebabkan terbentuknya struktur kepribadian yang relatif menyukai kedamaian, difokuskan pada kewajiban sebagai masyarakat sosial, keterbukaan untuk tujuan sebuah perubahan, dan kesadaran akan status sosial dan kekayaan.

\section{Budaya dan kepribadian di Amerika}

Sama halnya dengan masyarakat di Jepang, masyarakat di Amerika juga dapat dideskripsikan sebagai kelompok yang modern. Perkembangan masyarakat di Amerika pada dasarnya dipengaruhi oleh adanya perbandingan dan komposisi ras dan etnik sehingga memungkinkan timbulnya konflik. Pengalaman akan eksploitasi dan kekerasan yang disebabkan karena perbedaan ras dan etnik merupakan hal yang sangat sering dijumpai.

\section{Agresivitas}

Knorth, dkk. (2007) mendefinisikan agresif sebagai suatu perilaku yang membahayakan dan merusak baik secara pribadi maupun untuk orang lain. Perila$\mathrm{ku}$ agresif berhubungan dengan kondisi mental dan emosi dan sering dihubungkan dengan perilaku bullying, pernyataan, kekuatan, perilaku melanggar, dan pemarah. Berdasarkan penjelasan pada DSM IV perilaku agresif dapat diklasifikasikan sebagai conduct disorder (CD) dan oppositional defiant disorder (ODD). Karakteristik utama $C D$ adalah perilaku agresif secara langsung pada binatang dan manusia, dan kebohongan. Sedangkan pada ODD, perilaku agresif didefinisikan sebagai perilaku negative, musuh, dan ketidakpatuhan terhadap peraturan.

Ramirez, dkk. (2001) membagi agresif dalam dua dimensi, yaitu agresif secara objektivitas atau aksi dan agresif secara subjektivitas atau emosi. Objektivitas menunjukkan bahwa agresif merupakan perilaku praktis, eksplisit, dan eksternal.
Sedangkan subjektivitas menunjukkan bahwa agresif berhubungan dengan perasaan batin. Perasaan tersebut merupakan kombinasi antara pikiran, emosi, dan kecenderungan perilaku yang mengarah pada perilaku agresif. Knorth, dkk. (2007) membagi dua jenis perilaku agresif, yaitu agresif proaktif dan reaktif. Agresif proaktif dicontohkan pada remaja yang secara umum memiliki kemampuan sosial yang sesuai dengan aturan atau norma, memiliki kemampuan bahasa dan kecerdasan yang cukup baik, dan memiliki kontrol diri yang rendah dalam mencapai tujuan. Remaja dengan agresif proaktif biasanya membutuhkan kekuatan dan perhatian. Sedangkan agresif reaktif, lebih sering disebut hot blooded, yaitu otomatis dan sering melakukan kesalahan persepsi. Lebih cepat marah dan frustrasi.

Lebih lanjut dijelaskan oleh Knorth, dkk. (2007) bahwa secara etiologi, perilaku agresi disebabkan karena faktor biologi dan lingkungan. Sebagaimana yang telah dijelaskan oleh Bronfenbrenner terkait teori ekologi, yaitu eksosistem sampai makrosistem. Pada teori tersebut dijelaskan bahwa perilaku manusia terbentuk berdasarkan hasil interaksi antara individu dengan lingkungan. $\mathrm{Xu}$ dan Zhang (2008) mengemukakan bahwa perilaku agresif dan anti sosial merupakan masalah yang cukup besar yang terjadi di masa anak-anak, dan tidak menutup kemungkinan akan menimbulkan gangguan sosial.

Beberapa perilaku agresi dalam berbagai budaya

Berdasarkan hasil penelitian yang dilakukan oleh Brook secara cross-sectional pada anak-anak Afrika-Amerika dan Puerto Rican (2004) menunjukkan bahwa atribut kepribadian anak dan maternal secara signifikan memiliki korelasi terhadap perilaku agresif. Selain itu, faktor 
kebudayaan dan hubungan antara ibu dan anak juga memiliki pengaruh terhadap perilaku agresi. Vereycken (2002) juga menjelaskan bahwa konflik sebagai masalah yang pasif secara sistematis dalam beberapa penelitian diindikasi memiliki hubungan yang signifikan dengan gangguan kepribadian dan perilaku agresif. Berdasarkan diagnosis kepribadian pada DSM IV, gangguan kepribadian, seperti passive-aggressive memiliki prevalensi yang cukup tinggi terhadap timbulnya konflik ataupun perilaku agresif yang mengarah pada kekerasan. Selain itu, dalam buku PPDGJ yang dijelaskan oleh Maslim (2001) mendeskripsikan gangguan kepribadian dissosial sebagai bentuk perilaku yang ditandai dengan adanya sikap tidak peduli dengan perasaan orang lain, tidak bertanggung jawab dan terjadi secara terus-menerus, melampiaskan perilaku agresif termasuk tindak kekerasan, dan cenderung tidak peduli terhadap norma sosial yang berlaku.

Lebih lanjut Hensengerth (2011) mengemukakan beberapa bentuk kekerasan yang terjadi di kawasan Asia. Wacana kontemporer tentang kekerasan pada beberapa negara di Asia lebih mengarah pada kekerasan politik, seperti masalah kedaulatan negara perbatasan yang dihuni oleh kaum minoritas dimana akan menimbulkan konflik identitas (meliputi, Burma, Cina, Indonesia, dan Thailand) dan kekerasan terkait kebudayaan dan religiusitas. Analisis terkait penyebab konflik dan kekerasan pada tiap negara lebih mengacu pada bentuk dan system politik pada tiap-tiap negara. Konflik yang terjadi di Thailand merupakan sebuah bentuk pemberontakan yang dimulai setelah terjadinya Perang Dunia II. Konflik yang terjadi antara penduduk Muslim Melayu dengan Pemerintah Pusat Buddhist yang merupakan sebuah pemberontakan yang cukup besar yang terjadi pada tahun 1948. Konflik tersebut disebabkan karena keberadaan budaya, agama, ekonomi, dan politik yang merupakan sebuah cultural diskriminasi. Kekerasan yang terjadi di Mindanao disebabkan karena adanya pertikaian antar suku dan konflik antar etnik. Kekerasan yang terjadi di kalangan remaja dapat dipandang sebagai akibat dari adanya perubahan sosial. Dua puluh empat psikolog terutama yang berada di Jepang dan Singapura menjelaskan bahwa kekerasan yang terjadi di kalangan remaja merupakan bentuk self-help system sebagai hasil dari bentuk pengucilan sosial dalam lingkungan masyarakat paternalistik.

Xu dan Zhang (2008) mengemukakan terkait perilaku agresivitas reaktif dan proaktif pada anak-anak di China. Berdasarkan hasil penelitiannya dikemukakan bahwa perilaku agresif proaktif dan reaktif masing-masing ditemukan pada anak lakilaki dan perempuan. Anak dengan agresivitas reaktif menunjukkan perilaku disregulasi emosi, permusuhan, menampilkan perilaku yang tidak sesuai dengan kondisi lingkungan, kesepian, dan timbul kecemasan sosial. Berbeda dengan anakanak yang memiliki agresivitas proaktif, perilaku yang ditunjukkan meliputi perilaku yang lebih positif dibandingkan dengan agresi reaktif dan memiliki kepercayaan efikasi pada perilaku agresi. Penelitian terkait perilaku agresi di China juga diteliti oleh Chen, dkk. (2010) dimana kompetensi sosial dan pencapaian akademik memiliki hubungan resiprokal satu sama lain, meskipun keduanya tidak memiliki dampak yang signifikan. Beberapa literature mengindikasikan bahwa kompetensi sosial dan pencapaian akademik memiliki dampak terhadap penyesuaian diri, seperti afiliasi pada teman sebaya dan masalah internal lainnya. 


\section{Penutup}

Berdasarkan pemaparan dari beberapa kasus di berbagai wilayah di dunia dan di Indonesia, perilaku agresif merupakan suatu tindakan anti sosial yang dapat merusak diri sendiri dan lingkungan. Secara etiologi, penyebab perilaku agresif adalah faktor biologis dan lingkungan. Selain itu, atribut emosi terkait kematangan emosi juga memiliki hubungan dengan timbulnya perilaku agresif. Dijelaskan bahwa, individu yang memiliki tingkat kematangan emosi yang rendah lebih mudah berperilaku agresif dengan yang memiliki kematangan emosi yang tinggi. Pandangan secara empiris menjelaskan bahwa perilaku agresif dibedakan dalam dua jenis, yaitu agresivitas reaktif dan proaktif. Agresivitas proaktif memiliki karakteristik, seperti kemampuan sosial yang sesuai dengan aturan atau norma, memiliki kemampuan bahasa dan kecerdasan yang cukup baik, dan memiliki kontrol diri yang rendah dalam mencapai tujuan. Sedangkan agresivitas reaktif memiliki karakteristik, seperti sering melakukan kesalahan persepsi. Lebih cepat marah dan frustrasi.

Kepribadian dan agresitivas dalam berbagai budaya memiliki karakeristik yang bebeda-beda pula. Hal tersebut disebabkan faktor demografi yang memengaruhi terbentuknya kepribadian. Sifat/ temperamen terbentuk dari hasil interaksi antara faktor bawaan dan lingkungan. Sifat dan kepribadian tersebut akan menjadi perangai yang digunakan dalam berinteraksi dengan lingkungan sosial. Wacana kontemporer menjelaskan beberapa bentuk kekerasan yang terjadi di kawasan Asia. Analisis terkait penyebab konflik dan kekerasan pada beberapa negara tersebut mengarah pada kekerasan politik, seperti masalah kedaulatan negara perbatasan yang dihuni oleh kaum mino- ritas dimana akan menimbulkan konflik identitas dan kekerasan terkait kebudayaan dan religiusitas.

\section{Daftar Pustaka}

Brook, J. S., Rosenberg, G., Brook, D. W., Balka, E. B., \& Meade, M. (2004). Correlates of Agression in African American and Puero Rican Children. Journal of Genetic Psychology, 165(2), 185-202.

Castillo, R. J. (1997). Culture and Mental Illness: A Client-Centered Approach. Pacific Grove: Brooks/ Cole.

Chen, X., Huang, X., Chang, L., \& Li, D. (2010). Aggression, Social Competence, and Academic Achievement in Chinese: A 5-Year Longitudinal Study. Development and Psychology, 22, 583592.

Desmita. (2006). Psikologi Perkembangan. Bandung: PT Remaja Rosdakarya.

Geen, R. G. (2001). Human Eggression. Philadelphia, PA: Open University Press.

Guswani, A, M., \& Kawuryan, F. (2011). Perilaku Agresi pada Mahasiswa Ditinjau dari Kematangan Emosi. Jurnal Psikologi Pitutur, 1(2), 86-93.

Hasse, J. (2012). Anarkisme Demonstrasi Mahasiswa: Studi Kasus pada Universitas Islam Negeri Alauddin Makassar. Jurnal Studi Pemerintahan, 3(1), 45-65.

Hensengerth, O. (2011). Violence Research in Northeast and Southeast Asia: Main Themes and Directions. Politics and International Relations, 5(1), 55-86.

Knorth, E. J., Klomp, M., Bergh, P. M., \& Noom, M. J. (2007). Aggressive Adolscencents in Residential Care: A Selective Review of Treatment Requi- 
rements and Models. Adolescence, 42(167), 461-486.

Maslim, R. (2003). Buku Saku Diagnosis Gangguan Jiwa Rujukan Ringkas dari PPDGJ III. Jakarta: Unika Atmajaya.

Mousazadeh, Z., \& Asgharzade, N. (2012). Concept, Nature, and Samples of Aggression and Its Controlling Techniques with Emphasis on The Islamic Approach. Journal of Asian Social Science, 8(6).

Nisbett, R. E., \& Cohen, D. (1996). Culture of Honor: The Psychology of Violence in The South. Boulder, Co: Westview Press.

Raine, A., Brennen, P. A., Farrington, D. P., \& Mednick, S. A. (1997). Biosocial Bases of Violence. London: Plenum.
Ramirez, J. M., Lagerspetz, K., Fraczek, A., Fujihara, T., Musazahedeh, Z., \& Theron, W. H. (2001). Difference and Similarities in Moral Approval of Aggressive Acts: A Cross-National Study. Aggressive Behavior, 27(3), 225-6.

Schultz, D., Izard, C. E., \& Bear, G. (2004). Children's Emotion Processing: Relations to Emotionally and Aggression. Development and Psychology, 16, 371387.

Vereycken, J., Vertommen, H., \& Corveleyn, J. Authority Conflicts and Personality Dosirder. Journal of Personality Disorders, 16(1), 41-51.

Xu, Y., \& Zhang, Z. (2008). Distinguishing Proactive and Reactive Aggression in Chines Children. Journal of Abnormal Child Psychology, 36, 539-552. 